\title{
DEVELOPMENT OF TECHNOLOGY FOR THE HEMP STALKS PREPARATION
}

\author{
Victor Sheychenko \\ Poltava State Agrarian Academy, Ukraine \\ E-mail: victorseychenko@gmail.com \\ Ihor Marynchenko \\ Institute of Bast Crops of the National Academy \\ of Agrarian Sciences of Ukraine, Ukraine \\ E-mail: marinchenkoi@i.ua \\ Ihor Dudnikov \\ Poltava State Agrarian Academy, Ukraine \\ E-mail: igor.dudnikov@pdaa.edu.ua \\ Mykola Korchak \\ State Agrarian and Engineering University in Podilya, Ukraine \\ E-mail: korchak_nikolay@ukr.net \\ Submission: $24 / 11 / 2018$ \\ Revision: 31/12/2018 \\ Accept: 08/02/2019
}

\section{ABSTRACT}

Getting high-quality trusts in modern technology for growing technical hemp is one of the most labor-intensive processes. The main factors that cause loss of quality of hemp are determined by the level of perfection of the harvesting stage of the production process. It is precisely at this stage that the basic processes of product quality management are concentrated, the main physical and technological losses are taking place. The main drawbacks of the known methods of obtaining the trusts of technical hemp include the dependence of the process of forming its qualitative indicators on weather conditions, the unevenness of the separation and strength of the fiber on the entire mass of the sent layer, the length of the technological process, which determines the quantitative loss of production. 
The article presents the results of research on the development of resource-saving technology for the production of technical hemp trusts due to the addition of an outlet with improved water drains with reeds and finger-wheels and the direct effect of their constructive parameters on the quality indicators of the trust. The technology is carried out thanks to the developed unit, whose work involves operations: raking the stems with a decrease in the width of the roll by a wheel rake; rolling of the stalks by the modernized corrugated rolls with tearing off from the soil of the stalks; loosening the tape with finger wheels. It is established that an increase in the number of mechanical effects on the hemp strap tape leads to a corresponding decrease in its mass and height. As a result of three consecutive rolling's, the height of the windrow decreases by $66 \%$, and the weight, respectively, by $37 \%$. Loosening reduces to 2.1 $\mathrm{kg}$ per linear meter weight of the roll, which is about $55 \%$ of the initial level. Under such conditions, the prerequisites for the use of the roll technology of assembly of hemp trusts have been created, which makes it possible to effectively use balers when harvesting the stems of not only seed (wide-row) crops, but also green grass ones. Techniques for obtaining a hedge trustee make it possible to reduce the time of process implementation at the initial stages of its preparation for primary processing, intensifies the process of purification due to the additional mechanical drive with improved aggregates. The short fiber obtained from the hemp trust for the technology developed meets the existing requirements.

Keywords: Technology; hemp stalks; methods of hemp trusts preparation; unit for hemp stalks tape preparation; short fiber from the hemp stalks

\section{INTRODUCTION}

In modern production industrial hemp is considered to be a highly profitable crop, provided by the absence of waste from its processing. All constituent plants seeds, fiber (long, short), hemp awn (a by-product of fiber production) have a wide range of uses in many industries and national economy. Due to the unique natural properties of hemp, scientists constantly find new areas of non-traditional use for the plant that make it attractive for production.

A wide range of uses (textile and food industries, medicine, energy, auto and aircraft construction, construction, etc.) - convincingly demonstrates the promise of using technical hemp. 
In the process of hemp stalks preparation, the main parameters are formed that determine the qualitative and quantitative characteristics of the fiber. The technology of hemp stalks preparation is a sequence of complex biological and technological processes that begin with the wetting of hemp straw and continue with a number of technological operations: drying, stirring, baling the finished hemp stalks into rolls and transporting it to processing plants.

The main factors that determine the output of fiber during the hemp stalks preparation include the uneven lying of the stalks along the length and thickness of the tape. This indicator, in turn, depends on the uniformity of the layer of hemp in ribbons. Significant influence on the quality of the fibers have lengthiness of stems, the timing of spreading and preparing of hemp stalks.

The main imperfections of the known methods of obtaining stalks of technical hemp include: the dependence of the process of forming its quality indicators on weather conditions; the unevenness of the cross-linking and the strength of the fiber along the entire mass of the dispatched layer; a long duration of the technological process, which leads to a quantitative loss of production.

A resource-saving technology for obtaining hemp stalks has been developed, which allows optimizing the process of wetting at the initial stages of preparation for primary processing and intensifies the cleaning process of the stalks due to additional pressing with the help of improved mechanical influences. Due to this, there was a significant reduction in the time spent on obtaining and collecting trusts, the efficiency of the stages of its primary processing.

\subsection{Analysis of recent studies and publications}

The technology of harvesting hemp is different from the technology of harvesting other crops, because it requires a whole range of technological methods for preparing raw materials and equipment. And all this is due to the fact that the hemp plant has a rather complicated morphological structure in the presence of a fibrous component, which requires additional biological, chemical, physical and mechanical efforts in its destruction and splitting (JANKAUSKIENE், et al., 2017).

One of the important processes of primary processing of hemp stems, which further affects the quality of the final product (fiber), is the process of preparing stalks. (By mechanisms of destruction of bonds between fibers and tissues in the 
DOI: 10.14807/ijmp.v10i7.913

stem, the existing methods of preparing trusts can be divided into three groups: biological, chemical and physicochemical (JANKAUSKIENE், et al., 2015).

By a biological method, the breaking of bonds between fiber and wood in the stem is achieved through the use of the vital activity of various microorganisms, in particular bacteria and mold fungi (MISHCHENKO, et al., 2017).

To biological method of hemp stalks preparation it is possible to carry an aqueous watering (immersion of stalks in the water environment). Another method of biological wetting is dewed wetting, when the hemp stems, after collecting them, are spread on the field by a thin layer for the preparation of the stalk (DUVALL, 2015). Unlike water, where bacteria are the active substances, mold stimuli are the main pathogens in the case of dewed wetting. In the process of their vital activity, fungal spores produce substances (enzymes) that cause destruction of pectin substances and disrupt the bonds between tissues (WESTERHUIS, 2016).

Technology of dewed wetting can be used in winter and spring. Depending on the climatic zone, the process of dewed wetting during the autumn period can last 25-40 days or more (SHEYCHENKO; MARINCHENKO, 2014).

The main disadvantage of this method of hemp stalks preparation is a large dependence on weather conditions. In the case of unfavorable autumn weather (no precipitation, or vice versa, a large number, a decrease in the average daily temperature), the process of stalks preparing is delayed, as a result of which the stalks does not have time to prepare for the appearance of the first snow (PROBLEMS AND PROSPECTS IN BREEDING, GENETICS, TECHNOLOGY OF HARVESTING, PROCESSING AND STANDARDIZATION OF BARN CROPS, 2006).

To the dewed wetting can be attributed the way of preparing the stalks, when the stems, after cutting the seed in the fall, are left to stand on the root until the spring. With this method, the mechanism of tissue destruction is the same as in the spreading of stalks on the field (VENTURI, et al., 2007).

The disadvantage of this method of hemp stalks preparation is that the field is not released in the autumn, and in the spring the finished hemp stalks should be collected in a short time, which requires the use of additional equipment (KOLODINSKY, 1997). 
In the chemical method of preparation, trusts for tissue destruction create an environment that is favorable for pectin bacteria, thus stimulating the reproduction of the main and accompanying microflora.

The chemical method of preparing trusts is the method of wetting the stems in an aqueous solution with the addition of certain chemical preparations. The use of chemicals (ammonium sulfate, ammonia, carbonic acid and bicarbonate soda, etc.) allows you to speed up all natural processes and reduce the preparation time of trusts by $20-30 \%$ (up to 2.5 days). At the same time, due to chemical reactions, the quantitative and qualitative indicators of the fiber are improved: the breaking load and flexibility of the fiber increase, which allows increasing the percentage of its output (GILYAZETDINOV; BARANNIK, 2000).

However, the use of this method of hemp stalks preparation requires additional costs (financial, human, hourly), because the wetting liquid cannot be used many times (GILYAZETDINOV, 2009).

Also known physic-chemical method of preparing trusts, in which the breaking of bonds between tissues occurs by thermo-chemical hydrolysis, which occurs in the stems under the action of saturated steam and high temperature. To this method can be attributed to the method of preparing trusts by steaming. The peculiarity of this method is that sufficiently moistened hemp stalks are treated under steam pressure at ambient temperature (MAKAEV; LUKYANENKO; GILYAZETDINOV, 2006).

The best technological and operational properties are fiber obtained from stalks, prepared by water treatment and by steaming. However, as already noted above, the hemp stalks preparation by these methods provides for additional financial expenses and a large expenditure of manual labor. Therefore, the alternative is dewed wetting (KOROPCHENKO; GILYAZETDINOV; LUKYANENKO, 2006).

Note that each of the known methods of hemp stalks preparation has its own characteristics, advantages and disadvantages. A simpler and cheaper method of dewed wetting, since it does not require the use of the additional preparation, eliminates the need for construction of treatment plants, and the number of necessary workers can be reduced to a minimum (HAJLIS; KOVALEV, 1994). 
DOI: 10.14807/ijmp.v10i7.913

Thus, authors note that arose the problem of the need for the industry to switch to new energy and resource-saving technologies for the integrated preparation and processing of hemp raw materials, with the production of an undirected short fiber with specified final quality characteristics on its basis (KOROPCHENKO, 2004).

In the northern countries of the hemp zone such as Finland and in certain regions of Canada, the trusts are collected after the autumn-winter preparation. After harvesting the seed part with combine harvesters, the hemp stalks are left to winter in the field. By spring, the hemp straw is transform on the trust. This is primarily due to the peculiarities of the climatic conditions of these countries, namely the very short season of ripening. If hemp seeds have time to ripen, then obtaining trusts is associated with great difficulties.

This technology of preparation of hemp stalks consists of the following technological operations: mowing a combine harvester of the seed part of the stem in September, cracking at the root collar and chaotic spreading of the main part of the stem on the field surface due to processing by soil tillage rollers in OctoberNovember.

The preparation of trusts is carried out in the autumn-winter period by the method of freezing the stem. In early spring, under favorable weather conditions, the collection of finished hemp trusts is carried out (EHRENSING, 1998).

Since within Ukraine the proposed technology had no practical application, it remains an open question about the quality of the trusts obtained under this scheme, as well as the quality of the fiber obtained after processing (WASKO; KOZLOVWSKI; MARKOVSKI, 2004)

This will significantly expand the scope of application of hemp fibers in various sectors of the national economy of Ukraine and beyond. Therefore, the creation of new resource-saving technologies and equipment that would solve the problem of optimizing the hemp stalks preparation is an urgent task.

\subsection{Statement of the objective and tasks of the study}

The objective of the study is to increase the efficiency of the hemp industry by developing a new resource-saving technology for the production of hemp stalks. 
To achieve the set objective, the following tasks were solved:

- summarize the information on existing technological schemes, machines and mechanisms for preparing the tape of stems for collection and further processing and develop a resource-saving technology for obtaining hemp stalks;

- develop a technological scheme and perform a kinematics calculation of the working units of equipment for mechanical preparation of hemp stalks at separate stages;

- to carry out approbation of resource-saving technology for obtaining trusts on experimental equipment in the field;

- to investigate the quality of the fiber isolated after the processing of trusts obtained for resource-saving technology.

\section{RESULTS AND DISCUSSION}

Optimize the complex processes of the assembly cycle, and especially the process of hemp stalks preparation, is possible by combining them (combination). Due to this, it becomes possible to improve biological processes, and to save significant production resources. The most promising scientific direction of the radical solution of the problem of increasing the efficiency of technological processes for the hemp stalks preparation is the transition to methods that allow the intensification of the cleaning process of the stalks due to the additional action by improved corrugated water-filled roller and finger wheels. This, in aggregate, provides optimal conditions for obtaining final products with predicted indicators.

According to the working process of the aggregate (Figure 1), the windrow 4 , previously formed by rotary rakes, is subjected to an additional narrowing by the finger wheel hay rakes 1 . After this, depending on the raw material, are performed the rolling operation by a set of grooved rollers 2 (formed from one, two or three modernized rollers of different corrugation) and loosening operation with the help of finger wheels 3 .

In the technological process of forming a tape of hemp stems, it is proposed to use the following technique: a modernized corrugated water-filled roller KVG-1.4, hinged finger wheel hay rakes GVK-6, and round baler PRP-1,6 for picking up of the received mass. 


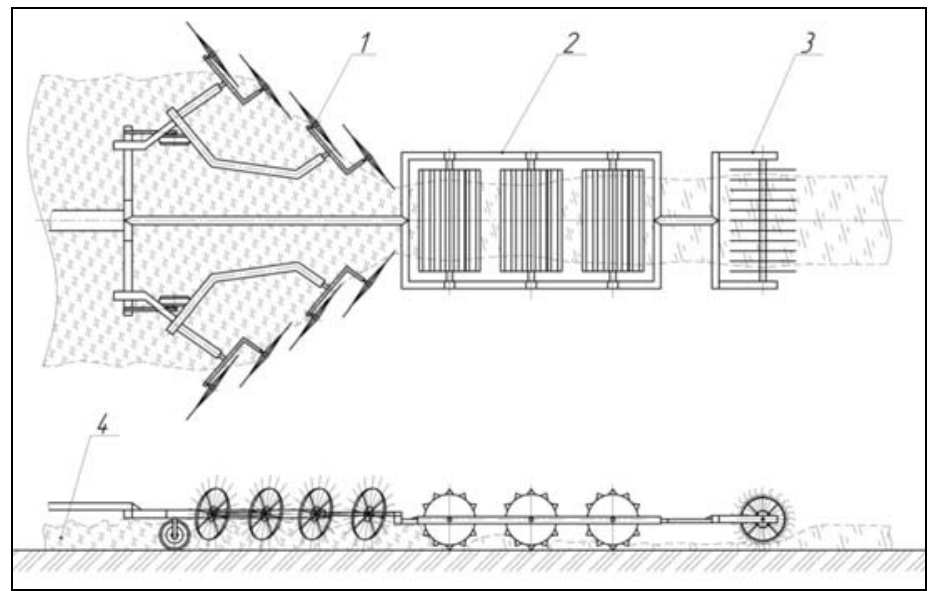

Figure 1: Technological scheme of the unit for the formation of tape and the hemp stalks preparation

In the process of modernization, the surface of the KVG-1,4 water-filled roller was equipped with 12-angle corrugations in $185.3 \mathrm{~mm}$ increments (Fig. 2).

The most common round baler PRP-1,6 in the farms can ensure stable performance of the technological process if the mass of stalks in the windrow does not exceed 2.5-2.7 kg per meter and the width of the it is $1.3 \mathrm{~m}$, and stems have a certain elasticity. Such windrow parameters can be provided only if the number of stems does not exceed 850-900 thousand pieces per ha. This can be when harvesting stems from seed (wide-row) crops, and the width of the field with which rake are performed in one pass does not exceed $6 \mathrm{~m}$.

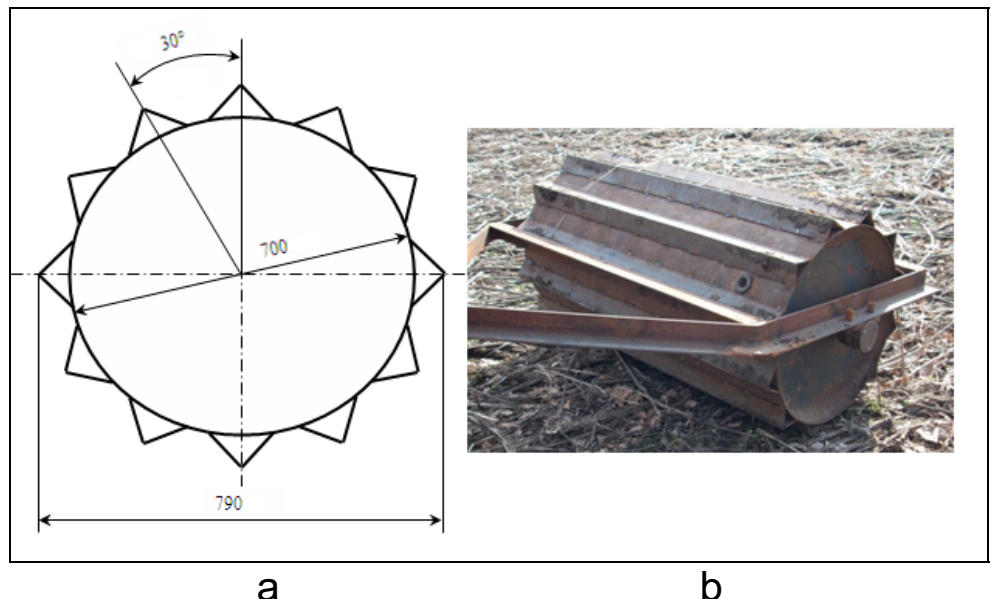

Figure 2: The modernized water-filled roller KVG-1,4 : a - the scheme of placing of riffles on a surface of a roller; $b$ - roller assembly

On continuous sowing, the density of stalk can reach values of 2000-2200 thousand pieces per ha. That is, the baler of the aforementioned brand at the 
harvesting of continuous sowing will not always be able to ensure a stable process, and the hemp stalks harvesting technology must also be used to collect hemp crops with a stalk density of more than 850-900 thousand pieces per ha. Therefore, one of the ways that will ensure these conditions is to reduce the width of the roll, increase the intensity of the process of breaking the stems and provide elasticity of raw materials. After the modernization of the section of the roller KVG-1.4, its weight was $350 \mathrm{~kg}$. The total weight of the three sections of the rollers in the coupling is $1050 \mathrm{~kg}$, in contrast to the existing ones, which have a weight of $977 \mathrm{~kg}$.

The use of modernized rollers, the total mass of which is increased to $1050 \mathrm{~kg}$ (by $7 \%$ compared with the prototype), creates prerequisites for managing the process of mechanical action on the tape of hemp stalks. This effect increases the rate of destruction of bonds between wood and fibers of the stalks, reduces their rigidity, accelerates the process of hemp trusts preparation. Note that the place on the stalks of hemp, subjected to mechanical stress, more actively moistened and populated by spores of fungi and bacteria. Under such conditions, the process $f$ hemp trusts preparation is accelerated.

The developed unit is designed for use in the preparation of hemp stalks tape. According to the technology of hemp harvesting, the following operations were used: threshing of the tops, cutting off the stems, forming a windrow, preparing the hemp stalks by laying it under the snow in winter and further rolling the hemp stalks in rolls. It should be noted that stems of hemp, in comparison with the stems of other crops, have significantly greater rigidity and strength, so the balers cannot stably perform the rolling operation.

The proposed unit provides the execution of operations raking stems with reduced width of the windrow and rolling of the stems with simultaneous tearing them off the ground by rippled rollers.

The rational technological parameters of the experimental unit were determined in order to find the most effective technological modes of operation of the proposed unit, depending on the input raw materials factors and the final qualitative indices of short hemp fibers

Based on the results of the research, rational technical characteristics of the aggregate for tape formation and hemp stalks preparation in roll coiling (shown 
above) were established and additional experimental studies were conducted to determine the effect of machining on the qualitative indicators of hemp stalks and best obtained by the new resource-saving technology.

Figures 3 and 4 show the results of studies of the change in the height of the windrow (Figure 3) and the mass of the stalks (Figure 4), depending on the number of mechanical actions of the working parts of the unit.

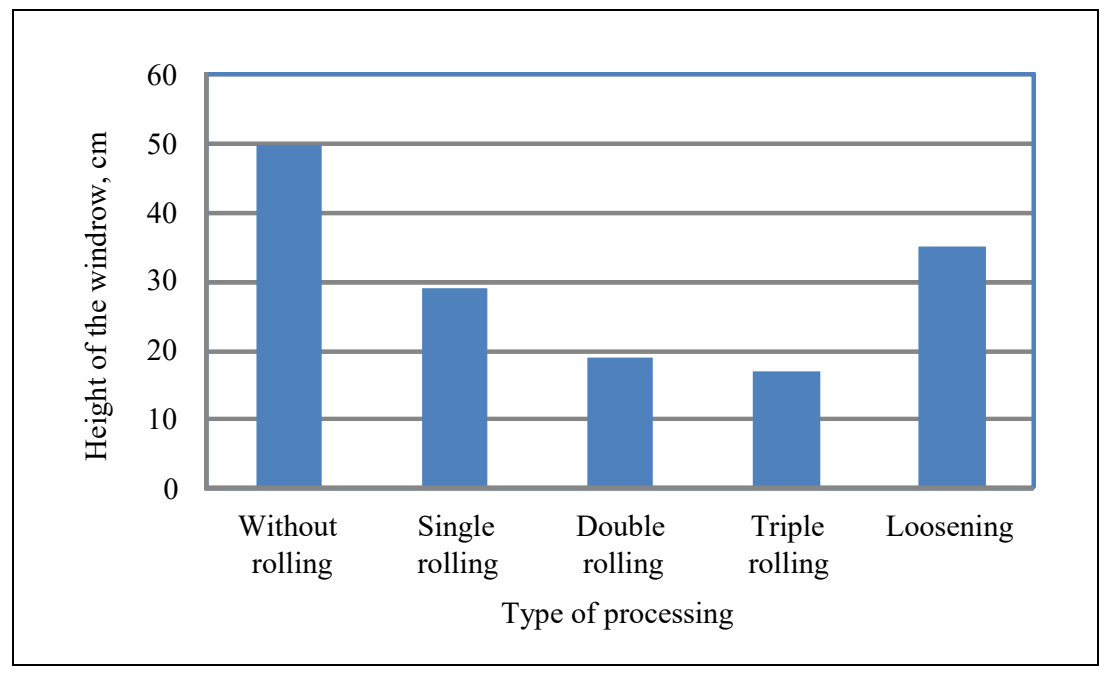

Figure 3: Dynamics of the change in the height of the windrow, depending on the number of mechanical actions of the working parts of the unit

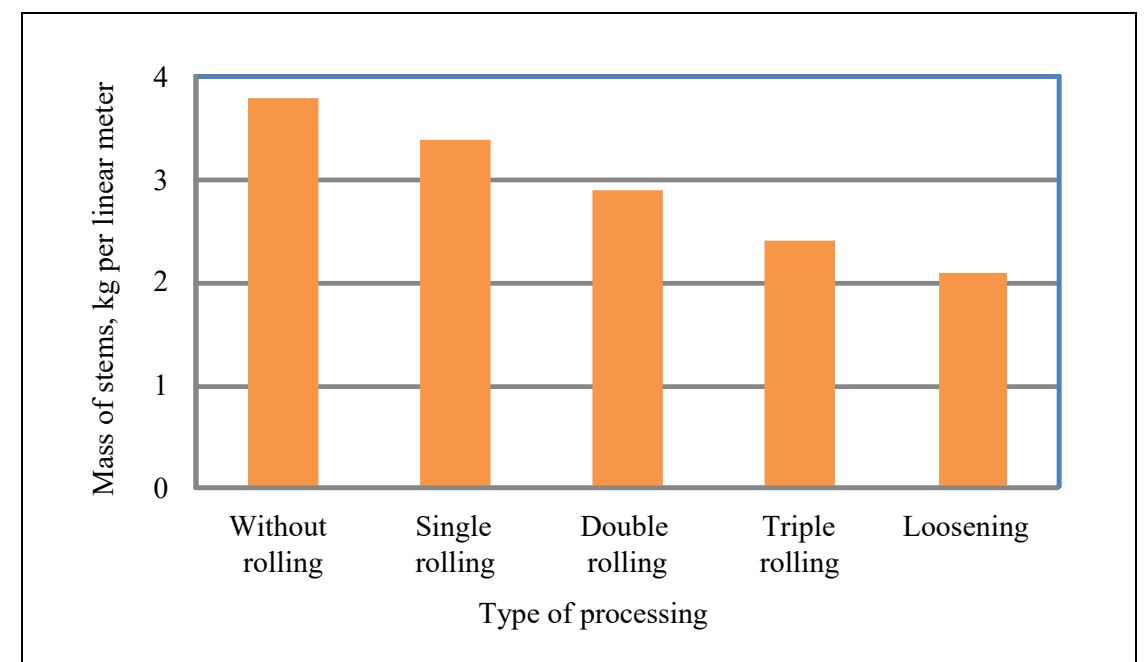

Figure 4: Dynamics of changes in the mass of stems, depending on the number of mechanical actions of the working parts of the unit

According to the results of the analysis of the studies shown in Fig. 3 and 4, it is established that an increase in the number of mechanical influences on the hemp stems tape (one-, two- and three-fold rolling) leads to a corresponding decrease in its height and mass. So with a single rolling, the height was $29.0 \mathrm{~cm}$ at a weight of $3.4 \mathrm{~kg}$ per linear meter. When double rolling, these values decreased to $19.0 \mathrm{~cm}$ and 
DOI: 10.14807/ijmp.v10i7.913

$2.9 \mathrm{~kg}$ per linear meter, respectively. And with triple rolling, they were $17.0 \mathrm{~cm}$ and $2.4 \mathrm{~kg}$ per linear meter. The loosening process reduces the weight of the tape to 2.1 $\mathrm{kg}$ per linear meter, but under such conditions the height of the roll increases to 35.0 $\mathrm{cm}$.

It is established that an increase in the number of mechanical effects on the hemp strap tape leads to a corresponding decrease in its mass and height. As a result of three consecutive rollings, the height of the windrow decreases by $66 \%$, and the weight, respectively, by $37 \%$. Loosening reduces to $2.1 \mathrm{~kg}$ per linear meter weight of the roll, which is about $55 \%$ of the initial level. Under such conditions, the prerequisites for the use of the roll technology of assembly of hemp trusts have been created, which makes it possible to effectively use balers when harvesting the stems of not only seed (wide-row) crops, but also greengrass ones.

Dynamics of changes in the number of broken stems and the number of breaks in the hemp stalk depending on the variant of the unit action are shown in Figure 5.

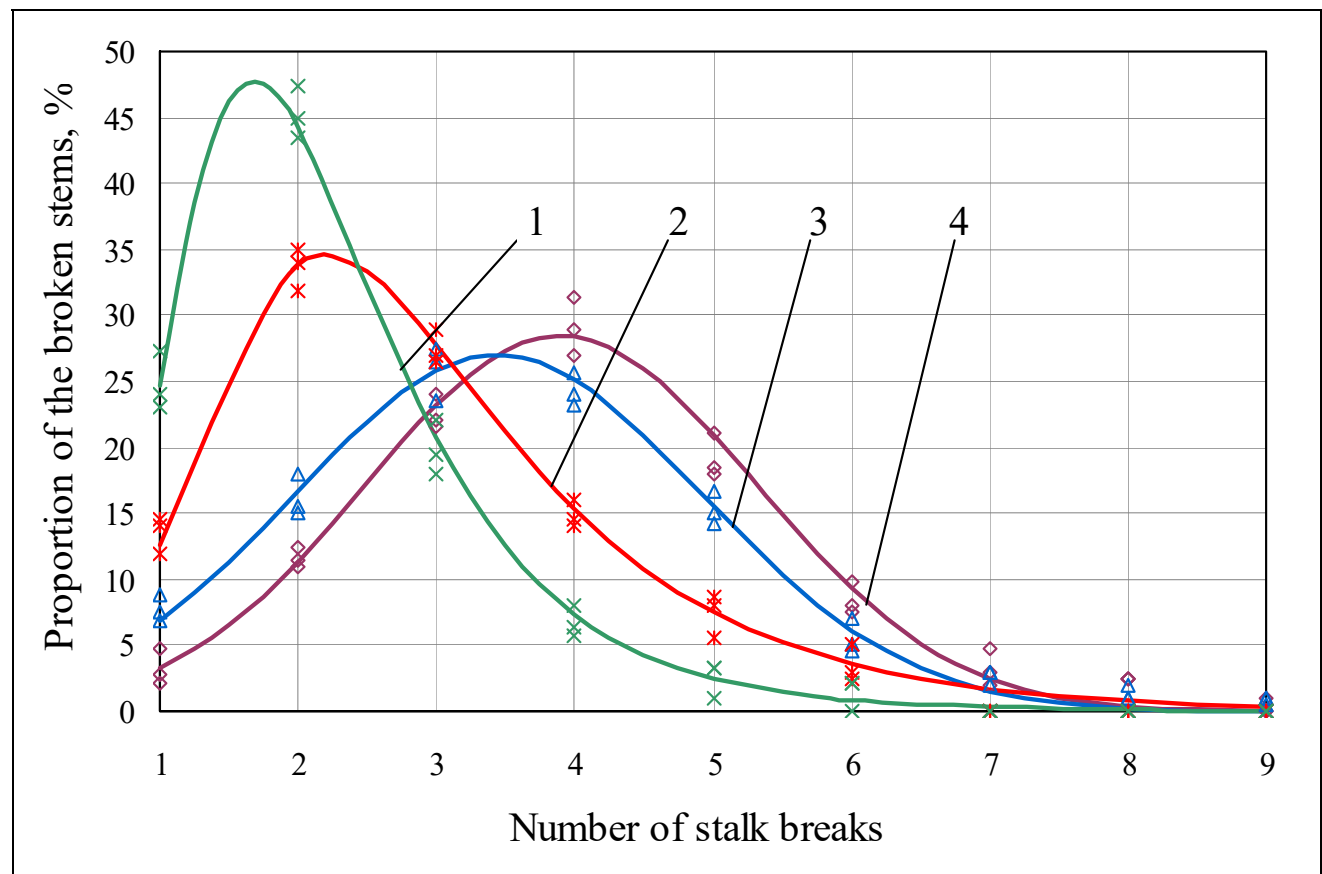

Figure 5: Dependence of the change in the number of breaks of stems depending on the action of the working parts of the unit: 1- without rolling; 2 - single rolling; 3 - double rolling; 4 - triple rolling

Analysis of graphical dependencies (Figure 5) shows that as the mechanical actions increase, damage to hemp stems grows. 
INDEPENDENT JOURNAL OF MANAGEMENT \& PRODUCTION (IJM\&P)

http://www.ijmp.jor.br

v. 10, n. 7, Special Edition PDATU 2019

ISSN: 2236-269X

DOI: 10.14807/ijmp.v10i7.913

It is noted that the parameters of the hemp stalk tape are within the normative values for the further formation of rolls. However, with an increase in the number of mechanical actions the damage to the stems also increases so it is necessary to investigate these processes in more detail.

For this purpose, the influence of the operations of mechanical preparation of the hemp stalks tape on the physical and geometric characteristics of the tape and the change in the qualitative indices of the short hemp fiber obtained were studied (Tables 1 and 2).

When processing the results of experimental studies used methods of regression analysis. The experimental dependencies were approximated using the least squares method using the statistical software package STATISTIKA-6.5. The adequacy test was carried out using the elements of analysis of variance using Fisher criterion at a confidence level of 0.95 .

The qualitative characteristics of the best obtained were evaluated according to the procedure given in Sec. 6.2 (STANDARDS PUBLISHING HOUSE, 2015).

Table 1: Influence of preparatory operations on changing the hemp stalks tape characteristics

\begin{tabular}{|l|c|c|c|c|}
\hline \multirow{2}{*}{\begin{tabular}{c}
\multirow{2}{*}{$\begin{array}{c}\text { Type of } \\
\text { processing }\end{array}$} \\
\cline { 2 - 5 }
\end{tabular}} & \multicolumn{2}{|c|}{ Height of windrow } & \multicolumn{2}{c|}{ Windrow mass, } \\
\hline Without rolling & 50.0 & 100 & kg per meter & $\%$ \\
\hline Single rolling & 29.0 & 58 & 3.8 & 100 \\
\hline Double rolling & 19.0 & 38 & 2.9 & 89.5 \\
\hline Triple rolling & 17.0 & 34 & 2.4 & 76,3 \\
\hline Loosening & 35.0 & 70 & 2.1 & 63.2 \\
\hline
\end{tabular}

Table 2: Influence of preparatory operations on the quality of short hemp

\begin{tabular}{|l|c|c|c|c|}
\hline \multirow{2}{*}{ Type of processing } & \multicolumn{4}{|c|}{ Qualitative indicators of the hemp } \\
\cline { 2 - 5 } & $\begin{array}{c}\text { Mass fraction } \\
\text { of awn, \% }\end{array}$ & $\begin{array}{c}\text { Mass fraction of } \\
\text { lublike strands, } \\
\%\end{array}$ & $\begin{array}{c}\text { Breaking } \\
\text { load, kg }\end{array}$ & $\begin{array}{c}\text { Deviation, } \\
\mathrm{kg}\end{array}$ \\
\hline Without rolling & 3.9 & 1.5 & 39.8 & \pm 7.86 \\
\hline Single rolling & 4.9 & 0.8 & 39.0 & \pm 7.98 \\
\hline Double rolling & 6.3 & 0.5 & 40.5 & \pm 8.29 \\
\hline Triple rolling & 2.1 & 0.3 & 39.5 & \pm 5.64 \\
\hline
\end{tabular}

Comparative analysis of the data presented in Table. 2 with the existing standards allow us to conclude that a short fiber obtained from the hemp stalks through a new resource-saving technology fully meets the existing requirements 
(STANDARDS PUBLISHING HOUSE, 2015; STANDARDS PUBLISHING HOUSE, 2016).

\section{CONCLUSIONS}

A resource-saving technology for obtaining the hemp stalks has been developed based on the results of the studies. The technology is carried out thanks to the developed unit, whose work involves operations: raking the stems with a decrease in the width of the roll by a wheel rake; rolling of the stalks by the modernized corrugated rolls with tearing off from the soil of the stalks; loosening the tape with finger wheels.

The use of modernized rollers, the total mass of which is increased to $1050 \mathrm{~kg}$ (by $7 \%$ compared with the prototype), creates prerequisites for managing the process of mechanical action on the tape of hemp stalks. This effect increases the rate of destruction of bonds between wood and fibers of the stalks, reduces their rigidity, accelerates the process of hemp trusts preparation.

It is established that an increase in the number of mechanical effects on the hemp strap tape leads to a corresponding decrease in its mass and height. As a result of three consecutive rollings, the height of the windrow decreases by $66 \%$, and the weight, respectively, by $37 \%$. Loosening reduces to $2.1 \mathrm{~kg}$ per linear meter weight of the roll, which is about $55 \%$ of the initial level. Under such conditions, the prerequisites for the use of the roll technology of assembly of hemp trusts have been created, which makes it possible to effectively use balers when harvesting the stems of not only seed (wide-row) crops, but also greengrass ones.

It has been established that a short fiber obtained from a hemp stalks through a new resource-saving technology fully meets the existing requirements of normative and technical documentation.

\section{REFERENCES}

DUVALL, C. (2015) Cannabis. Reaktion Books, London. ISBN: 9781780233413

GILYAZETDINOV, R. N. (2009) Development of scientific foundations for the creation of innovative technologies for the primary processing of barn crops. Thesis (Ph.D. in Engineering). Herson: HNTU.

EHRENSING, D. T. (1998) Feasibility of Industrial Hemp Production in the United States Pacific Northwest. Bulletin. Agricultural Experiment Station, Oregon 
INDEPENDENT JOURNAL OF MANAGEMENT \& PRODUCTION (IJM\&P)

http://www.ijmp.jor.br

v. 10, n. 7, Special Edition PDATU 2019

ISSN: 2236-269X

DOI: 10.14807/ijmp.v10i7.913

State University, Corvallis, OR. Available:

https://catalog.extension.oregonstate.edu/sites/catalog/files/project/pdf/sb681.pdf.

HAJLIS, G. A.; KOVALEV, M. M. (1994) Issledovanie selskohozjajstvennoj

tehniki i obrabotka opytnyh danyh, Moscow: Kolos.

JANKAUSKIENĖ, Z.; GRUZDEVIENĖ, E.; BURBULIS, N.; MAUMEVIČIUS, E.; LAYKO, I. M. (2015) Investigation of hemp (Cannabis sativa L.) crop weediness. In: $10^{\text {th }}$ INTERNATIONAL SCIENTIFIC AND PRACTICAL CONFERENCE «ENVIRONMENT. TECHNOLOGY. RESOURCES», REZEKNE, LATVIA V. II, 120123. Proceedings... Rezekne. DOI: http://dx.doi.org/10.17770/etr2015vol2.272

JANKAUSKIENĖ, Z.; GRUZDEVIENĖ, E.; MAUMEVIČIUS, E.; LAYKO, I. M. (2017) Investigation of hemp (Cannabis sativa $L$.) fibre quantity and quality as influenced by genotype and seed rate. Environment. Technology. Resources, v. 1, p. 125-128. DOI: 10.17770/etr2017vol1.2530

KOLODINSKY, J. (1997) Marketing of hemp products - the consumer is key. Institute of Natural Fibres. Poznan: Poland, Special Edition, p. 58-63.

KOROPCHENKO, S. P. (2004) Progressivnaya tehnologiya vyideleniya luba konopli $\checkmark$ vide odnorodnoy massyi. Problems of light and textile industry of Ukraine, v. 1, n. 8, p. 313-315.

KOROPCHENKO, S. P.; GILYAZETDINOV, R. N.; LUKYANENKO P. V. (2006) Shliakhy udoskonalennia tekhnolohii zbyrannia ta pererobky nasinnievykh konopel. Fashion \& Textiles Industry Journal, v. 2, p. 46-47.

MAKAEV, V. I.; LUKYANENKO, P. V.; GILYAZETDINOV, R. N. (2006)

Mekhanizatsiia zbyrannia zelentsevykh posiviv konopel. Agricultural machinery, v. 14, p. 130-137.

MISHCHENKO, S.; MOKHER, J.; LAIKO, I.; BURBULIS, N.; KYRYCHENKO, H.; DUDUKOVA, S. (2017) Phenological growth stages of hemp (Cannabis sativa L.): codification and description according to the BBCH scale. ŽEMĖS ÜKIO MOKSLAI. v. 24, n. 2, p. 31-36. DOI: https://doi.org/10.6001/zemesukiomokslai.v24i2.3496

SHEYCHENKO, V. O.; MARINCHENKO, I. O. (2014) Do pytannia oderzhannia lubovoloknystoi syrovyny z tekhnichnykh konopel. Agricultural machinery, v. 2930, p. 168-174.

STANDARDS PUBLISHING HOUSE (2015) Hemp fiber tow. Specifications, GOST 9993-2014, Standartinform, Moscow.

STANDARDS PUBLISHING HOUSE, (2016) Scutched hemp. Technical specification, GOST R 56560-2015, Standartinform, Moscow.

VENTURI, P.; AMADUCCI, S.; AMADUCCI, M. T.; VENTURI, G. (2007) Interaction between agronomic and mechanical factors for fiber crops harvesting: Italian Results. Journal of natural fibers. Colorado: The Haworth Press, p. 83-97. DOI: 10.1300/J395v04n03_06

WASKO, J.; KOZLOVWSKI, R.; MARKOVSKI, J. (2004) The state and the perspective of flax and hemp utilization in Poland and in the World. Euroflax, v. 1, p. 6-10. 
ISSN: 2236-269X

DOI: 10.14807/ijmp.v10i7.913

WESTERHUIS, W. (2016) Hemp for textiles: plant size matters. PhD thesis, University. Promotor(en): Paul Struik, co-promotor(en): Tjeerd-Jan Stomph; Jan van Dam. Wageningen : Wageningen University. ISBN 9789462577879. 234 p. 